УДК: 35:624:330.131.7

DOI: https://doi.org/10.32689/26172224-2019-17-2-57-65

\section{Гаврилов Андрій Володимирович,} аспірант кафедри публічного адміністрування, Міжрегіональна Академія управління персоналом, 03039, м. Київ, вул. Фрометівська, 2, тел.: +38 (067) 18572 02, e-mail: andrii.havrylov@gmail.com

ORCID: 0000-0001-9486-6603

\section{Гаврилов Андрей Владимирович,} аспирант кафедры публичного администрирования, Межрегиональная Академия управления персоналом, 03039, г. Киев, ул. Фрометовская, 2, тел.: +38 (067) 185 72 02, e-mail: andrii.havrylov@gmail.com

ORCID: 0000-0001-9486-6603

\section{Havrylov Andrii Volodymyrovych,} post-graduate student of Public Administration Department, Interregional Academy of Personnel Management, 03039, Kyiv, Str. Frometivska, 2, tel.: +38 (067) 1857202. e-mail: andrii.havrylov@gmail.com

ORCID: 0000-0001-9486-6603

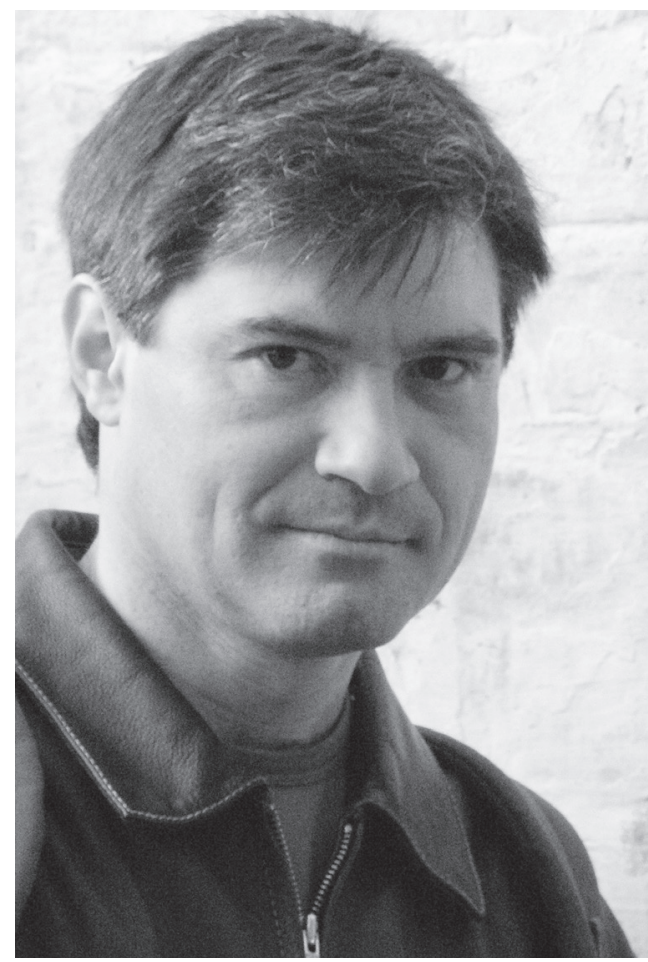

\title{
АНАЛІЗ РИЗИКІВ, ЩО ВИНИКАЮТЬ У ПРОЦЕСІ БУДІВНИЦТВА
}

Анотація. Проаналізовано ризики, що виникають у процесі реалізації інвестиційно-будівельних проектів. Розглянуто сутність поняття ризику, ідентифіковані джерела ризиків, здійснено класифікацію ризиків за сферою виникнення (ризики до завершення будівництва, ризики після завершення будівництва). Представлено методи аналізу ризиків, що виникають у процесі реалізації інвестиційно-будівельних проектів: метод аналогій, метод статистичного аналізу, метод аналізу чутливості, експертний метод, метод діаграм, нормативний метод.

Визначено основні наслідки реалізації ризиків та заходи щодо їх мінімізації. Встановлено, що принципове значення має об'єктивний та неупереджений аналіз ситуації, що склалася на інвестиційно-будівельному ринку в контексті загального стану у відповідному регіоні та в країні загалом. Виявлено необхідність своєчасної ідентифікації ризиків, які виникають під час реалізації проектів та визначено їх вплив на економічну та експлуатаційну складові будівництва. Розглянуто основні механізми управління ризиками, 
що представлені циклічними етапами, які тривають від початку і до моменту завершення проекту: виявлення і визначення ризику; розроблення кроків для зниження виявлених ризиків; впровадження розробленого плану в проект; проведення аналізу впровадження нагляду за реалізацією проекту. Використання представлених методів ідентинтифікації ризиків сприятиме підвищенню ефективності реалізації інвестиційно-будівельних проектів та зменшенню реальних витрат на реалізацію проектів, передбачених кошторисною документацією шляхом визначення можливих ризиків, їх ідентифікації та подальшому справедливому розподілі ідентифікованих ризиків між учасниками інвестиційно-будівельних проектів.

У більш детальних дослідженнях пріоритетним є питання розроблення методології управління ризиками під час реалізації інвестиційно-будівельних проектів та запровадження матричного підходу до розподілу ризиків між учасниками реалізації проектів.

Ключові слова: будівництво, ризик, управління ризиками, порушення, методи аналізу ризиків, технологічний процес, будівельні роботи, об'єкт будівництва, інвестиційно-будівельний проект.

\section{АНАЛИЗ РИСКОВ, ВОЗНИКАЮЩИХ В ПРОЦЕССЕ СТРОИТЕЛЬСТВА}

Аннотация. Проанализированы риски, возникающие в процессе реализации инвестиционно-строительных проектов. Рассмотрена суть понятия риска, идентифицированы источники рисков, осуществлена классификация рисков по сфере возникновения (риски до завершения строительства, риски после завершения строительства). Представлены методы анализа рисков, возникающих в процессе реализации инвестиционно-строительных проектов: метод аналогий, метод статистического анализа, метод анализа чувствительности, экспертный метод, метод диаграмм, нормативный метод. Определены основные последствия реализации рисков и меры по их минимизации. Установлено, что принципиальное значение имеет объективный и беспристрастный анализ ситуации, сложившейся на инвестиционно-строительном рынке в контексте общего положения в соответствующем регионе и в стране в целом. Выявлена необходимость своевременной идентификации рисков, возникающих во время реализации проектов и определено их влияние на экономическую и эксплуатационную составляющие строительства. Рассмотрены основные механизмы управления рисками, представленные циклическими этапами, которые продолжаются от начала и до момента завершения проекта: выявление и определение риска; разработка шагов для снижения выявленных рисков; внедрение разработанного плана в проект; проведение анализа внедрения надзора за реализацией проекта. Использование представленных методов идентинтификации рисков будет способствовать повышению эффективности реализации инвестиционно-строительных проектов и уменьшению реальных затрат на реализацию проектов, предусмотренных сметной документацией путем определения возможных 
рисков, их идентификации и дальнейшем справедливом распределении идентифицированных рисков между участниками инвестиционно-строительных проектов.

В более детальных исследованиях приоритетным является вопрос разработки методологии управления рисками во время реализации инвестиционно-строительных проектов и внедрение матричного подхода к распределению рисков между участниками реализации проектов.

Ключевые слова: строительство, риск, управление рисками, нарушения, методы анализа рисков, технологический процесс, строительные работы, объект строительства, инвестиционно-строительный проект.

\section{ANALYSIS OF THE RISKS OCCURRING DURING CONSTRUCTION}

Abstract. The article focuses on analyzing the risks that occur during implementation of investment construction projects. It analyzes the risk concept core, identifies risk sources, and classifies risks by the time of their occurrence (risks before the construction completion, risks after the construction completion). The article presents the methods used to analyze the risks that occur in the course of implementing investment construction projects: analogy method, statistical analysis method, sensitivity analysis method, examination method, diagram method, and normative method. Main consequences of risk realization are defined as well as ways of their mitigation. The article determines that of the principal importance is the impartial and unbiased analysis of the situation on the investment construction market in the context of the general state in a corresponding region and entire country. It is discovered that it is necessary to timely identify the risks happening during the project implementation. The risks' influence on the economic and operational components of construction is defined. The article reviews the basic mechanisms of risk management in cyclic stages lasting from the project commencement to its completion: identification and definition of a risk; development of measures to mitigate the revealed risks; implementation of the developed plan in the project; analyzing introduction of the project implementation supervision. Using the presented risk identification methods will encourage enhancing the effective realization of investment construction projects and decrease of actual expenses for project implementation, which are envisaged in the quantity surveying documents by revealing probable risks, their identification, and further fair allocation of the identified risks among the stakeholders of investment construction projects.

More detailed researches prioritize issues of developing a risk management methodology for implementation of investment construction projects and adoption of a matrix approach to risk allocation among the project realization stakeholders.

Keywords: construction, risk, risk management, violation, risk analysis methods, technological process, construction works, construction facility, investment construction project. 
Постановка проблеми. На сьогодні сучасне середовище, в якому функціонують підприємства будівельної галузі України, є надзвичайно складним. Конкуренція, швидка зміна кон'юнктури ринку, нестабільна політична ситуація породжують ризики в процесі реалізації інвестиційно-будівельних проектів.

Невизначеність ситуації призводить до неможливості уникнути ризиків, що виникають у процесі будівництва. Успіх реалізації інвестиційно-будівельних проектів залежить від того, наскільки правильно учасники реалізації таких проектів зможуть орієнтуватися у складних ситуаціях, яким чином будуть передбачені і враховані негативні фактори, що можуть вплинути на реалізацію проектів. Завдання керівного персоналу підприємства полягає не в уникненні ризику взагалі, а в передбаченні, оцінюванні та зведенні його негативних наслідків до мінімального рівня, що зумовлює необхідність навчитися управляти ризиками.

Аналіз останніх досліджень та публікацій. Вагомий внесок у розроблення теоретичних і прикладних проблем регулювання ризиків житлового будівництва зробили іноземні та українські науковці, зокрема В. В. Вітлінський, П. І. Верченко, М. Д. Гелей, Я. Й. Малик, Ю. О. Коновалов, О. В. Миронов, О. М. Непомнящий, Н. Й. Реверчук, С. К. Реверчук, I. В. Яхнеева.

Мета статті. Метою цієї роботи є класифікація ризиків, що виникають у процесі реалізації інвестиційно-будівельних проектів.

Виклад основного матеріалу. Для будівництва типовим є харак- терні порушення термінів будівництва об'єктів [1]. При цьому реальні витрати на реалізацію проектів перевищують витрати, передбачені кошторисною документацією. Виявлення причин порушень неминуче призводить до аналізу умов реалізації проекту і ризиків, які вплинули на різних етапах реалізації. Тому дуже важливо ідентифікувати джерела ризиків, а не концентруватися на виявленні окремих факторів виникнення ризиків [2]. Найпоширенішими причинами порушень, що виникають при реалізації інвестиційно-будівельних проектів, вважаються: втручання власника, недостатній досвід підрядника, недостатнє фінансування, низька продуктивність праці, повільне і некваліфіковане прийняття рішень, нераціональне планування та некомпетентність субпідрядників [3].

У роботах, присвячених дослідженню ризиків, у тому числі в логістичних системах і ланцюгах поставок, наведені різні параметри та сутність ризиків [4]. На підставі цієї інформації можна виділити такі варіанти визначення сутності ризику:

- ризик - це відхилення від очікуваного ходу подій;

- ризик - це баланс можливих доходів і збитків, баланс схильності та несхильність небезпекам втрат;

- ризик - як можливість часткового або повного неотримання доходу при настанні деяких небажаних подій;

- ризик - це ситуація або подія, настання якої може призвести до відхилень: негативних наслідків, i, водночас, надати позитивний вплив, тобто дати позитивний ефект. 
При цьому ймовірність або небезпека ризику представлена параметрами, оцінка яких дає змогу визначити значимість ризику. Останній варіант найповніше відображає сутність ризику і відповідає його визначенню за національним стандартом ДСТУ ISO 9000:2015 (ISO 9000:2015, IDT): "ризик - це вплив невизначеності, який виражається у відхиленні від очікуваного результату - позитивному чи негативному" [4]. Ризик часто визначається комбінацією наслідків подій і пов'язаних 3 ними ймовірностей виникнення [4]. Ймовірний ризик часто визначають по відношенню до потенційних подій i їх наслідків або до їх комбінації. При цьому в стандарті зазначається, що невизначеність є станом, пов'язаним із браком, навіть частково, інформації, розуміння або знання про подію, їі наслідки або ймовірності. $\mathrm{y}$ зв'язку з цим надзвичайно важливим у системі менеджменту організації $€$ збір, збереження та аналіз фактичної інформації про зовнішні та внутрішні фактори ризику [4].

Слід зазначити, що факторами, що обмежують ділову активність будівельних організацій, $є$ недолік замовлень на виконання робіт; конкуренція з боку інших компаній; нестача кваліфікованих робітників; високий рівень податків; неплатоспроможність замовників; висока вартість матеріалів, конструкцій, виробів; нестача і зношеність машин і механізмів; високий відсоток комерційного кредиту. Для підвищення конкурентоспроможності організацій у будівельній сфері необхідно розробити механізм управління ризиками, який дасть змогу запобігти появі збитків.
Механізм управління ризиками можна розділити на такі основних етапи:

- виявлення і визначення ризику;

- розробка кроків для зниження виявлених ризиків;

- впровадження розробленого плану в проект;

- проведення аналізу впровадження нагляду за реалізацією проекту.

Усі чотири етапи є циклічними і тривають від початку і до моменту завершення проекту. За сферою виникнення розрізняють ризики зовнішні та внутрішні [5].

Зовнішні ризики - це ризики, що викликані несприятливим впливом навколишнього макросередовища або об'єктів, функціонально пов'язаних із будівельною організацією (банки, інвестори, постачальники, податкові органи тощо). Внутрішні ризики - це ризики внаслідок прийняття неправильних рішень, які можуть бути викликані недостатньою увагою до аналізу і планування діяльності будівельної організації, недоліками існуючої системи прийняття рішень тощо. Ризики, пов'язані 3 проведенням будівельно-монтажних робіт, відносять до внутрішніх ризиків організації. Їх поділяють на дві основні групи:

- категорія A - ризики до завершення будівництва;

- категорія Б - ризики після завершення будівництва (у цій статті не розглядаються). При цьому ризики категорії Б можуть бути наслідком вияву ризиків категорії А.

Ризики категорії А приносять матеріальні збитки, збільшуючи вартість будівництва. Вияв цих ризиків пов'язаний з недосконалістю системи менеджменту якості будівельної 
організації, порушенням встановлених вимог.

До ризиків категорії А відносять:

- недотримання технологічного процесу при зведенні будинків;

- застосування неякісних будівельних матеріалів і/або конструкцій;

- перевищення термінів будівництва.

Наслідки реалізації ризику недотримання технологічного процесу при зведенні будинків полягають у необхідності перебудови об'єктів, що зводяться, та/або вже зведених об'єктів. Основними заходами щодо мінімізації таких ризиків є:

- авторський нагляд;

- контроль з боку забудовника шляхом залучення інженера-консультанта;

- встановлення системи штрафних санкцій за невиконання договірних зобов'язань з підрядником;

- страхування підрядником від помилок при будівництві та монтажу, недбалості робітників, технічного персоналу;

- формування фінансового резерBy;

Наслідки ризику застосування неякісних будівельних матеріалів i/ або конструкцій можуть призвести до різного роду дефектів, аж до руйнування об'єктів, що зводяться і/або зведених споруд, які, у свою чергу, зумовлюють можливість реалізації таких ризиків, як:

- заподіяння шкоди життю або здоров'ю будівельного персоналу;

- заподіяння шкоди життю або здоров'ю та/або майну третіх осіб при здійсненні будівельних робіт;

- судові розгляди тощо.
Наслідки реалізації даних ризиків полягають у виникненні додаткових витрат, зриві термінів здачі проекту, втраті ділової репутації. Основними заходами з мінімізації ризику застосування неякісних будівельних матеріалів і/або конструкцій є:

- контроль з боку забудовника, у тому числі шляхом залучення інженера-консультанта;

- встановлення системи штрафних санкцій за невиконання договірних зобов'язань із підрядником у частині використання неякісних будівельних матеріалів або виробів;

- встановлення номенклатури будівельних матеріалів та технологій при укладенні договірних відносин з підрядником, щоб виключити їх підміну підрядником на менш якісні;

- страхування підрядником від можливого руйнування споруд, що зводяться та/або зведених споруд;

- страхування підрядником від можливої загибелі будівельного персоналу або третіх осіб від дефектів будівельного матеріалу;

- формування фінансового резерBy.

Ризик перевищення термінів будівництва може виникнути за таких умов:

- недостатнє фінансування;

- помилки в проектуванні;

- перебої з постачанням будівельних матеріалів;

- нестача кваліфікованих кадрів.

Наслідки ризику полягають у виникненні непередбачуваних витрат і порушенні термінів здачі об'єкта. Основними заходами щодо мінімізації цього ризику є:

- авторський та технічний нагляд за будівництвом; 
- календарне планування будівництва;

- розроблення резервних схем постачання будівельних матеріалів;

- введення системи відповідних санкцій за порушення трудової дисципліни; вів.

- формування фінансових резер-

У будівельній сфері аналіз ризиків доцільно проводити на основі таких методів [6]:

Метод аналогій. Суть методу полягає у тому, що інформація, отримана на основі реалізації окремих об'єктів, може бути використана в подальшому, особливо якщо проект є типовим. Зокрема, дані, накопичені при будівництві об'єктів кожної черги, застосовуються при плануванні робіт і поставок матеріально-технічних ресурсів для об'єктів наступної черги.

Метод статистичного аналізу. Може використовуватися у поєднанні з іншими методами (насамперед, 3 методом аналогій). Цей метод застосовують для перевірки гіпотез впливу ризику при наявності необхідного обсягу інформації, що встановлює частоту виникнення події і величину заподіяної шкоди.

Метод аналізу чутливості. Цей метод дає можливість оцінити вплив різних факторів на ключові показники реалізації проекту. Для житлового будівництва такими факторами є зміна закупівельних цін, стабільність роботи технічних засобів, безперервність забезпечення будівельних ділянок матеріалами, якісне виконання зобов'язань підрядниками. При застосуванні методу аналізу чутливості оцінюють граничні значення факторів ризику. Аналіз чутливості допомагає виявити фактори, що максимально впливають на результати проекту і вибрати найбільш стійкий до ризиків варіант реалізації проекту.

Експертний метод. Цей метод заснований на аналізі та використанні точок зору, різних за напрямами для оцінювання параметрів ризиків.

Метод діаграм. Цей метод передбачає побудову та аналіз діаграм, що відображають причинно-наслідкові зв'язки, дозволяючи виявити передумови ризиків. Аналіз системних діаграм або діаграм процесів демонструє взаємозв'язок різних елементів, факторів і механізмів причинноcтi.

Нормативний метод. Цей метод передбачає співставлення реальних параметрів ризику із встановленими нормативними значеннями. Так, ліміти використання техніки на будівельних ділянках регламентовані відповідними нормативами, перевищення яких означає виникнення втрат внаслідок неефективного використання коштів. У практичній діяльності досить складно постійно тримати в зоні уваги всі перелічені джерела ризиків. Тому обов'язковою умовою ефективного управління ризиками є функціонування інформаційної системи 3 виділенням підсистеми моніторингу ризикових чинників. Безперервне надходження в систему актуальної і достовірної інформаціï, i оперативне оброблення дають змогу своєчасно реагувати на зміни різного рівня. Ефективний процес управління документованою інформацією в системі менеджменту якості є запорукою ефективного управління ризиками та мінімізації 
ïx впливу на результати роботи будівельної організації.

\section{Висновки та перспективи подаль-} ших досліджень. В умовах економічної нестабільності збільшується кількість ризиків, які впливають на реалізацію інвестиційно-будівельних проектів. Ці ризики загрожують учасникам таких проектів не тільки суттєвим зменшенням прибутків, а й можливими збитками.

На етапі ідентифікації ризиків велике значення має аналіз ситуації, що склалася на інвестиційно-будівельному ринку, а також загального стану в країні й регіоні для здійснення превентивних заходів з метою мінімізації ризиків. Тому необхідно виявляти чинники, що визначають рівень ризиків, та які можна класифікувати за їх відповідними категоріями та ознаками.

Незважаючи на те, що врахувати всі ризики, які можуть виникнути в процесі реалізації інвестиційно-будівельного проекту, неможливо, визначення методів аналізу ризиків 3 метою їх структуризації сприятиме ефективній реалізації інвестиційно-будівельних проектів шляхом визначення та мінімізації ризиків, які виникають на всіх стадіях реалізації проектів, а також шляхом їх справедливого розподілу.

Пріоритет у подальших дослідженнях 3 цього питання повинен надаватися розробленню методології управління ризиками при реалізації інвестиційно-будівельних проектів.

\section{СПИСОК ВИКОРИСТАНИХ ДЖЕРЕЛ}

1. Системи управління якістю. Основні положення і словник: ДСТУ ISO
9000:2015 (ISO 9000:2015, IDT). [Чинний від 2016-07-01]. - К.: ДП “УкрНДНЦ”, 2016. - IV, 45 с.

2. Непомнящий О. М. Методологія дослідження державного регулювання в контексті управління ризиками у будівництві / О.М.Непомнящий, О. В. Медведчук // Менеджер. Вісн. Донецького держ. ун-ту управління. -2018 . - № 1 (78). - С. 15-19.

3. Вітлінський В. В. Аналіз, моделювання та управління економічним ризиком: навч.-метод. посіб. для самост. вивч. дисц. / В. В. Вітлінський, П. І. Верченко. - К.: КНЕУ, 2000. $292 \mathrm{c}$.

4. Яхнеева I. В. Управління ризиками в логістичних системах і ланцюгах поставок. - Самара: Вид-во СГЕУ, 2012. - $126 \mathrm{c}$.

5. Коновалов Ю. О., Миронов О. В. Система управління ризиками: поняття, функції, компоненти // Інноваційна Економіка. № 9 [47]. - 2013. - C. $127-$ 132.

6. Реверчук С. К., Реверчук Н. Й., Малик Я. Й., Гелей М. Д. Економічна безпека України: внутрішні i зовнішні чинники : навч. посіб. Л. : Вид. центр ЛНУ ім. І. Франка, 2002. -256 c

\section{REFERENCES}

1. Nepomniashchyi O. M., Medvedchuk O. V. (2018). Metodolohiia doslidzhennia derzhavnoho rehuliuvannia v konteksti upravlinnia ryzykamy u budivnytstvi [Methodology of the study of state regulation in the context of risk management in construction]. Menedzher. Visnyk Donetskoho derzhavnoho universytetu upravlinnia - Manager Bulletin of the Donetsk State University of Managemen, 1 (78), 15-19 [in Ukrainian].

2. Vitlinskyi V. V., Verchenko P. I. (2000). Analiz, modeliuvannia ta upravlin- 
nia ekonomichnym ryzykom [Analysis, modeling and management of economic risk]. Kyiv: KNEU [in Ukrainian].

3. Systemy upravlinnia yakistiu. Osnovni polozhennia i slovnyk: DSTU ISO 9000:2015 (ISO 9000:2015, IDT) [Quality management systems. Basic provisions and vocabulary: DSTU ISO 9000: 2015 (ISO 9000: 2015, IDT)]. (2016). Kyiv: DP "UkrNDNTs" [in Ukrainian].

4. Yakhneeva I. V. (2012). Upravlinnia ryzykamy $\mathrm{v}$ lohistychnykh systemakh i lantsiuhakh postavok [Risk management in logistics systems and supply chains]. Samara: Vydavnytstvo SHEU [in Ukrainian].

5. Konovalov $\mathrm{Yu}$. O., Myronov O. $V$. (2013). Systema upravlinnia ryzykamy: poniattia, funktsii, komponenty [Risk Management System: Concept, Functions, Components]. Innovatsiina Ekonomika - Innovative Economics, 9 (47), 127-132 [in Ukrainian].

6. Reverchuk S. K., Reverchuk N. Y., Malyk Ya. Y., Helei M. D. (2002). Ekonomichna bezpeka Ukrainy: vnutrishni i zovnishni chynnyky [Economic security of Ukraine: internal and external factors]. Lviv: Vyd. tsentr LNU imeni I. Franka [in Ukrainian]. 